\title{
Effect of Food Additives on the Productivity of Silk Worm Bombyx mori L.
}

\author{
Nagda, A.El-Sayed ${ }^{1}$, Mesbah H.A., ${ }^{1}$ M. A. El- Seehy ${ }^{2}$, Magda, B.A.EL-Kady ${ }^{1}$ and Omaima M.M. \\ El-Gamel $^{1}$
}

\begin{abstract}
The aim of the present work is to study the effect of supplementing mulberry leaves with two types of honey and palm pollen either alone or mixed at a level of different concentrations on certain biological and reproductive parameters of the mulberry silkworm Bombyx mori $\mathrm{L}$. particularly silk and egg production. The obtained results indicated that the treatment of mulberry leaves with mixture of citrus honey and palm pollen at a level of $5 \mathrm{mg}+$ $1 \mathrm{gm} / 100 \mathrm{ml}$ water significantly increased the biological parameters in comparison with that of the control. The treatments of both mixed types of honey bee with palm pollen increased moth's productivity and gave higher values in the egg production.
\end{abstract}

\section{INTRODUCTION}

The mulberry silkworm Bombyx mori L. is a beneficial insect producing the finest natural silk. Silk is called the Queen of textiles. The silkworm has long been considered as a monophagous insect with mulberry leaves as a known feed for a long time. The growth rate of Bombyx mori L. larvae and subsequent silk production depend mainly on the nutrient content of mulberry leaves. Fukuda (1960) reported that about $70 \%$ of silk protein produced by the B. mori is directly derived from the protein contents of mulberry leaves. Kumaraj et al., (1972) mentioned that the important factor influencing the growth and production of silkworm is the nutritional factor. The silkworms Bombyx mori L. require certain essential carbohydrates, proteins, amino acids, fatty acids, sterols and minerals for the growth of silk gland. and higher production of egg and silk (Ito, 1978). The nutritional elements of mulberry leaves determine the growth and development of the larvae and cocoon production (Seidavi et al., 2005). Many attempts have been made to improve the quality and quantity of silk. Mulberry leaves have been supplemented with various nutrients for silkworm feeding to promote silk quality and quantity. The supplementation and fortification of mulberry leaves is a recent technique in sericulture research (Murugan et al., 1998). Saikatsu et al., (1989). studied the effect of admixing royal jelly in artificial diets on the growth, development, weight of cocoons and the number of eggs laid by the silkworm of $B$. mori. The importance of honey in the nutrition of silkworm was reported by several works (e.g El-Hattab (1985), El-Karaksy et al., (1989)and Nagda El-Sayed (1999). Moreover, AlZannoon et al., (2008) evaluated the efficiency of two varieties of mulberry leaves (Morus alba var Kokuso-27 and Morus indica var. Kanva-2) compared withthat of Morus alba var. Balady (native), for adopting the best feeding schedule for Bombyx mori L larvae. The present work aimed to evaluate the nutritional efficiency of Carob honey (Ceratonia siliqua), Citrus honey (Citrus $s p$.), and palm pollen (Phoenix sp.) and their mixtures for determining beneficial effect of each or these substances on the productivity of Bombyx mori $\mathrm{L}$.

\section{MATERIALS AND METHODS}

The experiment was carried out on the Chinese F1 hybrid 9F7X of mulberry silkworm Bombyx mori L. the insect was reared at hygrothermic conditions of $25^{\circ} \mathrm{c} \pm$ $2{ }^{\circ} \mathrm{c}$ and $75 \pm 5 \%$ R.H.

The larvae were fed on fresh clean mulberry leaves until $4^{\text {th }}$ instar. Only the raised $5^{\text {th }}$ larval instar grouped in separate trays and used in the experiment.

\section{Substances:}

Two types of honey, palm pollen and their mixtures were tested as supplementary nutrients for the silkworm B. mori, these substances were as follows:

\section{Honey:}

\section{Carob honey (Ceratonia siliqua):}

Is somewhat rare, Carob honey is dark and crystallizes easily into a soft coarse texture. It has a medium aromatic intensity. Its tastes very similar to chocolate.

\section{Citrus honey (Citrus sp.):}

Light amber to white, the lighter color and milder flavor coming in years when there is a copious flowering large harvest and the honey is little contaminated by other nectars.

\section{Palm pollen (Phoenix spp.):}

Palm pollen is a fine powder containing the microgametophytes, which produce the male gametes (sperm cells). Pollen grains have a hard coat that protects the sperm cells during the process of their

\footnotetext{
${ }^{1}$ Plant Protection Dep., Fac. Agric., Saba Basha, Alex. Univ., Egypt

${ }^{2}$ Genetic Dep., Fac. Agric., Alex. Univ., Egypt

Received May 20, 2013, Accepted June 24, 2013
} 
movement from the stamens to the pistil of flowering plants.

\section{Experimental design:}

The experiments included nine of tested substance alone treatments and eighteen treatments of admixed ones in addition to control (Table 1). Every treatment was replicated three times. Each replicate contained 15 fifth instar larvae. The mulberry leaves were dipped in the prepared dilutions of abovementioned substances and demonstrated in table 1 .

After the leaves being dried, they were introduced to the larvae. For control, larvae were supplied with untreated leaves.

\section{Estimation of studied parameters:}

Fresh weights of mature $5^{\text {th }}$ instar larvae, pupae, fresh cocoons and cocoon shells were weighted. Prior to spinning cocoons, a sample of three mature experimented larvae was dissected and the silk glands were drawn and weighted.

Randomly selected three emerged female moths of the performed treatments were allowed to mate with three male moths, each couple was kept in its numerical paper bag. After oviposition, the number of deposited eggs per female moth was counted and recorded.

Also, the effective rate of rearing (E.R.R) as calculated and recorded according to this following equation

E.R.R $=$ No. of cocoon harvested $\chi 100 /$ total No.of larvae reared.

Data were subjected to the analysis of variance ANOVA Test and the least significant differences (LSD) at the 5\% level were determined according to computer program (COSTAT) and Duncan's Multiple Range Testes modified by Steel and Torrie (1981) to compare the estimated means of the inspected paramaters at different intervals.

\section{RESULTS AND DISCUSSION}

Effect of added food additives alone and /or mixed to mulberry leaves on some biological parameters of silkworm Bombyx mori L.

\section{- Effect of food additives alone:-}

The results in Table, 2 illustrate the mean weights of full grown larvae and it was found to be significantly different. It is shown that the use of tested pollen rates of $\mathrm{Po}_{2}, \mathrm{Po}_{4}$ and $\mathrm{Po}_{1}$ gave the heaviest weights of larvae (4.005, 3.75 and 3.67 g., respectively), while the mean weight of control larvae amounted to $(3.56 \mathrm{~g})$. The least mean weight of larvae has been achieved by using $\mathrm{Co}_{1}$ $(2.97 \mathrm{~g})$.

Significant differences were noted between the measured mean weights of silk gland in the control and made treatments. A similar trend of results was determined for the estimated weight of silk gland; the heaviest weight of silk gland was achieved by $\mathrm{Po}_{2}$ (0.51g).

Also the results showed revealed that a similar trend was attained for pupal weight, so the heaviest weight of pupa was obtained in treatment $\mathrm{Po}_{2}$ and comprised 1.609 g. with $0.382 \%$ increase over control. The lightest weight $\left(0.965 \mathrm{~g}\right.$.) was indicated for the treatment of $\mathrm{Co}_{1}$ $(0.965 \mathrm{~g})$ with a decrease -0.262 than the control.

The results in Table, 3 indicate that $\mathrm{Po}_{2}$ and $\mathrm{Po}_{4}$ gave the heaviest weights of cocoon and cocoon shell with an average of $1.962 \mathrm{~g}, \quad 0.61 \mathrm{~g}$ and $1.827 \mathrm{~g}, \quad 0.515$, respectively. The heaviest obtained weight of cocoon in the $\mathrm{PO}_{2}$ treatment gave a rate of $0.312 \%$ increase over control.

Moreover, the included results in Table, 3 proved that both treatment of $\mathrm{Po}_{2}$ and $\mathrm{Po}_{4}$ gave the highest number of laid eggs with an average of 509.33 and 482.33 eggs/female with $92 \%$ and $65 \%$ increase over control followed by the treatment of $\mathrm{Po}_{1}$ and $\mathrm{C}_{5} 450.33$ and 429.67 eggs in respect. The lowest calculated average (122.66 eggs/ female) was recorded from the $\mathrm{Co}_{1}$ which gave minor results in most tests. Also, the greatest E.R.R. was achieved by PO1(100\%)followed by C1 $(96.296 \%)$ and C3(96.296\%).

\section{Effect of food additives mixtures:-}

Results in Table, 4 summarized the effect of the tested materials on the mean weight of larva, mean weight of silk gland and mean weight of pupa. The $\mathrm{C}_{5} \mathrm{Po}_{1}$ gave the heaviest mean of larva, silk gland and pupa weight of $4.168 \mathrm{~g}, 0.538 \mathrm{~g}$ and $1.828 \mathrm{~g}$., respectively with an increase $0.603 \%, 0.186 \%$ and $0.645 \%$ over control., respectively. The lowest weight of larva 2.833 g. was recorded for the mixture $\mathrm{Co}_{3} \mathrm{po}_{1}$ with an increase $-0.732 \%$ over control.

At the same time, the weight of cocoon in experimental sets showed an increase in the weight of cocoon over the control. Whereas the highest and lowest mean weight of cocoon were observed by $\mathrm{C}_{5} \mathrm{Po}_{1}$ $(2.127 \mathrm{~g})$ and $\mathrm{Co}_{3} \mathrm{PO}_{1} 1.24(1.24 \mathrm{~g})$, respectively (Table 5).The results obtained in table (5) show that the treatment of mulberry leaves with food additives reflected on the weight of cocoon, cocoon shell and number of total eggs. The heaviest weight of cocoon shell was obtained from C5Po1 that comprised $0.413 \mathrm{~g}$. with $0.156 \%$ increase over control.

The present results in Table, 5 indicate that $\mathrm{C}_{5} \mathrm{Po}_{1}$ and $\mathrm{Co}_{1} \mathrm{Po}_{1}$ gave the greatest results with an average of 735.66 and 643.66 eggs/female followed by the $\mathrm{Co}_{5} \mathrm{Po} 1$ and $\mathrm{c} \mathrm{po}_{4}$ with $267.33 \%$ and $175.33 \%$ increase over control. The lowest calculated average (150.66 eggs/ 
female) was recorded from the $\mathrm{Co}_{3} \mathrm{Po}_{1}$ which gave minor results in most tests. Also, the greatest E.R.R. were achieved by $\mathrm{C}_{1} \mathrm{Po}_{1}, \mathrm{C}_{3} \mathrm{Po}_{2}, \mathrm{C}_{3} \mathrm{Po}_{4}, \mathrm{C}_{5} \mathrm{Po}_{2}$ and $\mathrm{C}_{5} \mathrm{Po}_{4}$ $(100 \%)$ followed by $\mathrm{Co}_{1} \mathrm{Po}_{1}, \mathrm{Co}_{3} \mathrm{Po}_{4}, \mathrm{C}_{1} \mathrm{Po}_{2}, \mathrm{C}_{1} \mathrm{Po}_{4}$, $\mathrm{C}_{5} \mathrm{Po}_{1}$ and control $(96.296 \%)$.
However, these results are in accordance with Hashida (1961) who stated that honey is a valuable agent that can be added to mulberry leaves and those reported by Nagda El-Sayed (1989 and 1994),

Table 1. The tested concentrations of adopted treatments (individuals and mixtures) of different types of tested substances

\begin{tabular}{ccccccc}
\hline $\begin{array}{c}\text { Substance } \\
\begin{array}{c}\text { Palm pollen (PO) } \\
(\mathbf{g m})\end{array}\end{array}$ & $\mathbf{1}$ & $\mathbf{3}$ & $\mathbf{5}$ & $\mathbf{1}$ & $\mathbf{3}$ & $\mathbf{5}$ \\
\hline 1 & $1 \mathrm{~g}+1 \mathrm{ml}$ & $1 \mathrm{~g}+3 \mathrm{ml}$ & $1 \mathrm{~g}+5 \mathrm{ml}$ & $1 \mathrm{~g}+1 \mathrm{ml}$ & $1 \mathrm{~g}+3 \mathrm{ml}$ & $1 \mathrm{~g}+5 \mathrm{ml}$ \\
\hline 2 & $2 \mathrm{~g}+1 \mathrm{ml}$ & $2 \mathrm{~g}+3 \mathrm{ml}$ & $2 \mathrm{~g}+5 \mathrm{ml}$ & $2 \mathrm{~g}+1 \mathrm{ml}$ & $2 \mathrm{~g}+3 \mathrm{ml}$ & $2 \mathrm{~g}+5 \mathrm{ml}$ \\
\hline 4 & $4 \mathrm{~g}+1 \mathrm{ml}$ & $4 \mathrm{~g}+3 \mathrm{ml}$ & $4 \mathrm{~g}+5 \mathrm{ml}$ & $4 \mathrm{~g}+1 \mathrm{ml}$ & $4 \mathrm{~g}+3 \mathrm{ml}$ & $4 \mathrm{~g}+5 \mathrm{ml}$ \\
\hline
\end{tabular}

Table 2. Effect of certain food additives to mulberry leaves on some biological parameters of silkworm Bombyx mori L.

\begin{tabular}{|c|c|c|c|c|c|c|c|c|c|}
\hline \multirow{3}{*}{$\begin{array}{c}\text { Treatment } \\
\text { Co1 }\end{array}$} & \multirow{2}{*}{\multicolumn{2}{|c|}{$\begin{array}{l}\text { Weight of } \\
\text { larva (g) }\end{array}$}} & \multirow{2}{*}{\multicolumn{2}{|c|}{$\begin{array}{l}\text { Weight of silk } \\
\text { gland (g) }\end{array}$}} & \multirow{2}{*}{\multicolumn{2}{|c|}{$\begin{array}{l}\text { Weight of } \\
\text { pupa }(g)\end{array}$}} & \multicolumn{3}{|c|}{ \% increase over control } \\
\hline & & & & & & & \multirow{2}{*}{$\begin{array}{c}\begin{array}{c}\text { Weight of } \\
\text { larva }\end{array} \\
-0.595 \\
\end{array}$} & \multirow{2}{*}{$\begin{array}{c}\begin{array}{c}\text { Weight of } \\
\text { silk gland }\end{array} \\
-0.026 \\
\end{array}$} & \multirow{2}{*}{$\begin{array}{c}\begin{array}{c}\text { Weight of } \\
\text { pupa }\end{array} \\
-0.262 \\
\end{array}$} \\
\hline & 2.97 & $\mathrm{f}$ & 0.322 & $\mathrm{e}$ & 0.965 & $\mathrm{~g}$ & & & \\
\hline $\mathrm{Co} 3$ & 3.037 & ef & 0.435 & $\mathrm{bc}$ & 1.122 & $\mathrm{f}$ & -0.528 & 0.087 & -0.105 \\
\hline $\mathrm{Co5}$ & 3.233 & $\mathrm{e}$ & 0.427 & $\mathrm{bc}$ & 1.135 & $\mathrm{f}$ & -0.332 & 0.079 & -0.092 \\
\hline $\mathrm{C} 1$ & 3.457 & $\mathrm{~d}$ & 0.455 & $\mathrm{~b}$ & 1.15 & $\mathrm{f}$ & -0.108 & 0.107 & -0.077 \\
\hline $\mathrm{C} 3$ & 3.487 & $\mathrm{~cd}$ & 0.375 & $\mathrm{~d}$ & 1.193 & $\mathrm{e}$ & -0.078 & 0.027 & -0.034 \\
\hline $\mathrm{C} 5$ & 3.598 & bcd & 0.337 & $\mathrm{e}$ & 1.257 & $\mathrm{~d}$ & 0.033 & -0.011 & 0.03 \\
\hline Po1 & 3.677 & $\mathrm{bc}$ & 0.412 & $\mathrm{c}$ & 1.348 & $\mathrm{c}$ & 0.112 & 0.064 & 0.121 \\
\hline Po2 & 4.005 & $\mathrm{a}$ & 0.51 & $\mathrm{a}$ & 1.609 & $\mathrm{a}$ & 0.44 & 0.162 & 0.382 \\
\hline Po4 & 3.757 & $\mathrm{~b}$ & 0.455 & $\mathrm{~b}$ & 1.48 & $\mathrm{~b}$ & 0.192 & 0.107 & 0.253 \\
\hline Cont & 3.565 & $\mathrm{bcd}$ & 0.348 & $\mathrm{de}$ & 1.227 & $\mathrm{de}$ & 0 & 0 & 0 \\
\hline LSD .05 & 0.1 & & 0.0 & & 0.0 & & & & \\
\hline
\end{tabular}

Table 3. Effect of certain food additives to mulberry leaves on silk and egg production of silkworm Bombyx mori L.

\begin{tabular}{|c|c|c|c|c|c|c|c|c|c|}
\hline \multirow{3}{*}{$\begin{array}{c}\text { Treatment } \\
\text { Co1 }\end{array}$} & \multirow{2}{*}{\multicolumn{2}{|c|}{$\begin{array}{l}\text { Weight of } \\
\text { cocoon }(g)\end{array}$}} & \multirow{2}{*}{\multicolumn{2}{|c|}{$\begin{array}{l}\text { Weight of } \\
\text { cocoon } \\
\text { shell }(g)\end{array}$}} & \multirow{3}{*}{$\begin{array}{c}\begin{array}{c}\text { No. of } \\
\text { total egg }\end{array} \\
122.67 \mathrm{e}\end{array}$} & \multicolumn{3}{|c|}{$\%$ increase over control } & \multirow{3}{*}{$\begin{array}{l}\text { E.R.R. } \\
92.593\end{array}$} \\
\hline & & & & & & \multirow{2}{*}{$\begin{array}{c}\begin{array}{c}\text { Weight of } \\
\text { cocoon }\end{array} \\
-0.41\end{array}$} & \multirow{2}{*}{$\begin{array}{c}\begin{array}{c}\text { Weight of } \\
\text { cocoon shell }\end{array} \\
-0.072\end{array}$} & \multirow{2}{*}{$\begin{array}{c}\begin{array}{c}\text { No. of } \\
\text { total egg }\end{array} \\
-294.666\end{array}$} & \\
\hline & 1.24 & $\mathrm{f}$ & 0.275 & $\mathrm{c}$ & & & & & \\
\hline $\mathrm{Co} 3$ & 1.556 & $\mathrm{~d}$ & 0.3 & $\mathrm{c}$ & $178.33 \mathrm{de}$ & -0.094 & -0.047 & -239.003 & 96.296 \\
\hline Co5 & 1.47 & $\mathrm{e}$ & 0.303 & $\mathrm{c}$ & 263 cde & -0.18 & -0.044 & -154.333 & 88.889 \\
\hline $\mathrm{C} 1$ & 1.803 & $\mathrm{~b}$ & 0.313 & $\mathrm{c}$ & 286 bcde & 0.153 & -0.034 & -131.333 & 96.296 \\
\hline $\mathrm{C} 3$ & 1.703 & $\mathrm{c}$ & 0.32 & $\mathrm{c}$ & 365 abcd & 0.053 & -0.027 & -52.333 & 96.296 \\
\hline C5 & 1.435 & $\mathrm{e}$ & 0.353 & $\mathrm{c}$ & $429.67 \mathrm{abc}$ & -0.215 & 0.006 & 12.334 & 96.296 \\
\hline Po1 & 1.652 & $\mathrm{c}$ & 0.477 & $\mathrm{~b}$ & $450.33 \mathrm{abc}$ & 0.002 & 0.13 & 33 & 100 \\
\hline $\mathrm{Po} 2$ & 1.962 & $\mathrm{a}$ & 0.61 & $\mathrm{a}$ & $509.33 \mathrm{a}$ & 0.312 & 0.263 & 92 & 96.296 \\
\hline Po4 & 1.827 & $\mathrm{~b}$ & 0.515 & $\mathrm{~b}$ & $482.33 \mathrm{ab}$ & 0.177 & 0.168 & 65 & 96.296 \\
\hline Cont & 1.65 & $\mathrm{c}$ & 0.347 & $\mathrm{c}$ & 417.33abc & 0 & 0 & 0 & 96.296 \\
\hline LSD .05 & 0.068 & & 0.077 & & 181.533 & & & & \\
\hline
\end{tabular}


Table 4. Effect of certain food additives to mulberry leaves on some biological parameters of silkworm Bombyx mori L.

\begin{tabular}{|c|c|c|c|c|c|c|c|c|c|}
\hline \multirow{3}{*}{$\begin{array}{c}\text { Treatment } \\
\text { Co1Po1 }\end{array}$} & \multirow{2}{*}{\multicolumn{2}{|c|}{$\begin{array}{l}\text { Weight of } \\
\text { larva }(g)\end{array}$}} & \multirow{2}{*}{\multicolumn{2}{|c|}{$\begin{array}{c}\text { Weight of } \\
\text { silk gland (g) }\end{array}$}} & \multirow{2}{*}{\multicolumn{2}{|c|}{$\begin{array}{l}\text { Weight of } \\
\text { pupa (g) }\end{array}$}} & \multicolumn{3}{|c|}{ \% increase over control } \\
\hline & & & & & & & \multirow{2}{*}{$\begin{array}{c}\begin{array}{c}\text { Weight of } \\
\text { larva }\end{array} \\
0.498 \\
\end{array}$} & \multirow{2}{*}{\begin{tabular}{|c|}
$\begin{array}{l}\text { Weight of } \\
\text { silk gland }\end{array}$ \\
0.113 \\
\end{tabular}} & \multirow{2}{*}{$\begin{array}{c}\begin{array}{c}\text { Weight of } \\
\text { pupa }\end{array} \\
0.589\end{array}$} \\
\hline & 4.063 & $a b$ & 0.465 & $\mathrm{~b}$ & 1.772 & $\mathrm{~b}$ & & & \\
\hline Co1Po2 & 3.673 & fgh & 0.383 & ef & 1.21 & hi & 0.108 & 0.031 & 0.027 \\
\hline Co1Po4 & 3.544 & $\mathrm{i}$ & 0.35 & ghi & 1.147 & $\mathrm{j}$ & -0.021 & -0.002 & -0.036 \\
\hline Co3Po1 & 2.833 & 1 & 0.322 & $\mathrm{i}$ & 0.965 & 1 & -0.732 & -0.03 & -0.218 \\
\hline Co3Po2 & 3.27 & $\bar{j}$ & 0.327 & hi & 1.06 & $\mathrm{k}$ & -0.295 & -0.025 & -0.123 \\
\hline Co3Po4 & 3.843 & cde & 0.43 & $\mathrm{~cd}$ & 1.335 & $\mathrm{f}$ & 0.278 & 0.078 & 0.152 \\
\hline Co5Po1 & 4.025 & $\mathrm{~b}$ & 0.453 & $\mathrm{bc}$ & 1.722 & $\mathrm{c}$ & 0.46 & 0.101 & 0.539 \\
\hline Co5Po2 & 3.528 & $\mathrm{i}$ & 0.335 & hi & 1.115 & $\mathrm{j}$ & -0.037 & -0.017 & -0.068 \\
\hline Co5Po4 & 3.54 & $\mathrm{i}$ & 0.338 & hi & 1.118 & $\mathrm{j}$ & -0.025 & -0.014 & -0.065 \\
\hline C1Po1 & 3.898 & $\mathrm{~cd}$ & 0.435 & $\mathrm{c}$ & 1.358 & $\mathrm{f}$ & 0.333 & 0.083 & 0.175 \\
\hline C1Po2 & 3.15 & $\mathrm{k}$ & 0.322 & $\mathrm{i}$ & 0.975 & 1 & -0.415 & -0.03 & -0.208 \\
\hline C1Po4 & 3.762 & ef & 0.403 & $\mathrm{de}$ & 1.24 & gh & 0.197 & 0.051 & 0.057 \\
\hline C3Po1 & 3.575 & ghi & 0.37 & fg & 1.193 & $\mathrm{i}$ & 0.01 & 0.018 & 0.01 \\
\hline C3Po2 & 3.687 & fg & 0.397 & ef & 1.213 & hi & 0.122 & 0.045 & 0.03 \\
\hline C3Po4 & 3.955 & $\mathrm{bc}$ & 0.443 & $\mathrm{bc}$ & 1.43 & $\mathrm{e}$ & 0.39 & 0.091 & 0.247 \\
\hline C5Po1 & 4.168 & $\mathrm{a}$ & 0.538 & $a$ & 1.828 & $\mathrm{a}$ & 0.603 & 0.186 & 0.645 \\
\hline C5Po2 & 3.782 & def & 0.407 & $\mathrm{de}$ & 1.272 & $\mathrm{~g}$ & 0.217 & 0.055 & 0.089 \\
\hline C5Po4 & 4.023 & $\mathrm{~b}$ & 0.447 & $\mathrm{bc}$ & 1.657 & $\mathrm{~d}$ & 0.458 & 0.095 & 0.474 \\
\hline Cont & 3.565 & hi & 0.352 & $\mathrm{gh}$ & 1.183 & $\mathrm{i}$ & 0 & 0 & 0 \\
\hline LSD .05 & \multicolumn{2}{|c|}{0.112} & \multicolumn{2}{|c|}{0.026} & \multicolumn{2}{|c|}{0.035} & & & \\
\hline
\end{tabular}

$\mathrm{Co}=$ Carob honey, $\mathrm{Po}=$ Palm pollen, $\mathrm{C}=$ Citrus honey and $\mathrm{Cont}=$ Control

* Means followed with the same letter (s) are not significantly different.

Table 5. Effect of certain food additives to mulberry leaves on silk and egg production of silkworm Bombyx mori L.

\begin{tabular}{|c|c|c|c|c|c|c|c|c|c|c|}
\hline \multirow{3}{*}{$\begin{array}{c}\text { Treatment } \\
\text { Co1Po1 }\end{array}$} & \multirow{2}{*}{\multicolumn{2}{|c|}{$\begin{array}{c}\text { Weight of } \\
\text { cocoon } \\
(\mathrm{g})\end{array}$}} & \multirow{2}{*}{\multicolumn{2}{|c|}{$\begin{array}{c}\begin{array}{c}\text { Weight of } \\
\text { cocoon shell } \\
(\mathrm{g})\end{array} \\
\end{array}$}} & \multirow{2}{*}{\multicolumn{2}{|c|}{$\begin{array}{l}\text { No. of total } \\
\text { egg }\end{array}$}} & \multicolumn{3}{|c|}{$\%$ increase over control } & \multirow{3}{*}{$\begin{array}{c}\text { E.R.R } \\
96.296 \\
\end{array}$} \\
\hline & & & & & & & \multirow{2}{*}{$\begin{array}{c}\begin{array}{c}\text { Weight } \\
\text { ofcocoon }\end{array} \\
0.677 \\
\end{array}$} & \multirow{2}{*}{$\begin{array}{c}\begin{array}{c}\text { Weight of } \\
\text { cocoon shell }\end{array} \\
0.148 \\
\end{array}$} & \multirow{2}{*}{\begin{tabular}{|c|}
$\begin{array}{c}\text { No. of } \\
\text { total egg }\end{array}$ \\
175.334 \\
\end{tabular}} & \\
\hline & 2.127 & $\mathrm{a}$ & 0.405 & $\mathrm{a}$ & 643.67 & $\mathrm{ab}$ & & & & \\
\hline Co1Po2 & 1.475 & $\mathrm{~g}$ & 0.278 & fg & 536.33 & $\mathrm{bc}$ & 0.025 & 0.021 & 68 & 88.889 \\
\hline Co1Po4 & 1.447 & hi & 0.238 & gh & 372.33 & de & -0.003 & -0.019 & -96 & 85.185 \\
\hline Co3Po1 & 1.24 & $\mathrm{k}$ & 0.068 & $\mathrm{j}$ & 150.67 & $\mathrm{f}$ & -0.21 & -0.189 & -317.666 & 92.593 \\
\hline Co3Po2 & 1.25 & $\mathrm{k}$ & 0.128 & $\mathrm{i}$ & 256 & ef & -0.2 & -0.129 & -212.333 & 85.185 \\
\hline $\mathrm{Co} 3 \mathrm{Po} 4$ & 1.608 & de & 0.307 & cdef & 558.33 & $\mathrm{bc}$ & 0.158 & 0.05 & 90 & 96.296 \\
\hline Co5Po1 & 2.01 & $\mathrm{~b}$ & 0.395 & $a b$ & 618.33 & $a b c$ & 0.56 & 0.138 & 150 & 85.185 \\
\hline Co5Po2 & 1.34 & $\mathrm{j}$ & 0.14 & $\mathrm{i}$ & 263 & ef & -0.11 & -0.117 & -205.333 & 81.481 \\
\hline Co5Po4 & 1.44 & $\mathrm{i}$ & 0.203 & $\mathrm{~h}$ & 356 & de & -0.01 & -0.054 & -112.333 & 88.889 \\
\hline C1Po1 & 1.633 & $\mathrm{~cd}$ & 0.332 & cde & 578.67 & abc & 0.183 & 0.075 & 110.334 & 100 \\
\hline C1Po2 & 1.247 & $\mathrm{k}$ & 0.078 & $\mathrm{j}$ & 227.67 & ef & -0.203 & -0.179 & -240.666 & 96.296 \\
\hline C1Po4 & 1.537 & $\mathrm{f}$ & 0.293 & ef & 544.33 & $\mathrm{bc}$ & 0.087 & 0.036 & 76 & 96.296 \\
\hline C3Po1 & 1.473 & gh & 0.275 & fg & 497 & bcd & 0.023 & 0.018 & 28.667 & 92.593 \\
\hline C3Po2 & 1.517 & $\mathrm{f}$ & 0.287 & efg & 539 & $\mathrm{bc}$ & 0.067 & 0.03 & 70.667 & 100 \\
\hline C3Po4 & 1.635 & $\mathrm{~cd}$ & 0.343 & $\mathrm{~cd}$ & 590 & $a b c$ & 0.185 & 0.086 & 121.667 & 100 \\
\hline C5Po1 & 2.127 & $\mathrm{a}$ & 0.413 & $\mathrm{a}$ & 735.67 & $\mathrm{a}$ & 0.677 & 0.156 & 267.334 & 96.296 \\
\hline $\mathrm{C} 5 \mathrm{Po} 2$ & 1.583 & $\mathrm{e}$ & 0.298 & def & 553 & $\mathrm{bc}$ & 0.133 & 0.041 & 84.667 & 100 \\
\hline C5Po4 & 1.645 & $\mathrm{c}$ & 0.353 & $\mathrm{bc}$ & 607.67 & $a b c$ & 0.195 & 0.096 & 139.334 & 100 \\
\hline Cont & 1.45 & ghi & 0.257 & fg & 468.33 & $\mathrm{~cd}$ & 0 & 0 & 0 & 96.296 \\
\hline LSD .05 & 0.026 & & 0.044 & & 141.993 & & & & & \\
\hline
\end{tabular}

$\mathrm{Co}=$ Carob honey, $\mathrm{Po}=$ Palm pollen, $\mathrm{C}=$ Citrus honey and Cont $=$ Control. E.R.R.=Effective rate of rearing \%

* Means followed with the same letter (s) are not significantly different. 
Govindan et al., (1988), El-Karaksy and Idriss (1990), Muniandy et al., (1995), Sarker et al (1995) and Manoharan (1997) who found that the detected parameters of fitness component of Philosamia ricini Boisd or Bombyx mori L. larvae were significantly affected by the evaluated food additives. Nagda ElSayed et al (1996) found that the black cumin at 10 and $20 \%(\mathrm{w} / \mathrm{v})$ gave the heaviest weights of larvae, silk gland and male and female pupae of the mulberry silkworm B. mori L.. Also, Nagda El-Sayed (1999) reported that the mixture of honey and black cumin seeds gave the heaviest weights of larvae, pupae and dry silk gland. Also Magda Abd El- Aziz,. (2002) found that larvae treated with some vegetable oils gave high efficiency on the mean weight of cocoon shell and number of deposited eggs/female at low concentration of $0.05 \%$.

Ngukue et al., (2007) found that the treatment of late age silkworm larvae with royal jelly elicits favourable response in improving the commercial qualities of silk fibre and can be used in sericulture for yield enhancement. Zah et al., (2011) used different sources of fat on four different silkworm hybrid strands, they observed an increase in the individual mass and silk quantity compared to the control.

In conclusion the results of the present study proved the significant efficiency of the use of honey, oils and mixtures of them in improving the biometrics of Bombyx mori $\mathrm{L}$. leading to increase of silk and egg production.

\section{REFERENCES}

AI- Zannoon, A.H. ; E. M.M. Hassan; S. S. El-Akkad; I. M. Abdel-Nabi and S. M. Zalat (2008). Biological and technological effects of mulberry varieties and nutritional additives on silkworm Bombyx mori development. Egy. J. of Biol., 2008, Vol. 10, pp 1-10

El-Karaksy, I. A., S. M. El-Hattab and S. M. Moustafa. (1989). Eri silkworm Philosamia ricini Boisd. powdered pupae as an important source of protein in its semi artificial diet. Seventh Arab Pesticide conf., Tanta Univ. $118-125$.

El-Karaksy, I. A. and M. Idriss. (1990). Ascorbic acid enhances the silk yield of the mulberry silkworm Bombyx mori L. J. Appl. Ent. 109: 81 - 86.

Fukuda, T. (1960). Biochemical studies on the formation of silk protein. Part IX. The direct and indirect formation of the silk protein during growth of silkworm larva. Bullet Agric. Chem., Soc., Jap., 24:396-401.

Govindan, R.; S. B. Magadum and T. K. Narayanawami. (1988). Effect of supplementing vitamins B2, B6 and C to Eri - silkworm, Samia cynthia ricini Bosid. On economic traits. Agric. Sci. (1): $80-82$.
Hashida, K. (1961). Effect of royal jelly on silkworm larvae Bombyx mori L. Apic. Abstr. : 305.

Ito, T. (1978). Silkworm nutrition. Ln: the silkworm : An important laboratory tool (Ed. Y. Tazima). Kodansga Ltd. Tokyo. Pp.307.

Kumaraj, S.; S. Vijayaraghavan and S. Krishnaswami. (1972). Studies on fortification of mulberry leaves for feeding silkworms. Int. J. Ser. 11 (1): $68-72$.

Magda Abd El-Aziz,. (2002). Influence of some vegetable oils on mulberry silkworm, Bombyx mori L. productivity. $2^{\text {nd }}$ International conference, Plant Protection Research Instirute, Cairo, Egypt, 21 - 24 Dec, 2002.

Manoharan, T. (1997). A study of hydrolyzed soybean protein supplementation on the reproductive system of mulberry silkworm Bombyx mori L. Ph. D. Thesis. Jamal Mahamed College, Bharathidasan University, Trivchirappalli, India.

Muniandy, S.; M. Sheela and S. T. Nirmala. (1995). Effect of vitamins and minerals (Filibon) on food intake, growth and conversion efficiency in Bombyx mori L. Environ. and Ecol 13 (2) : 433 - 435.

Murugan, K. ; D. Jeyabalan ; K. N. Senthil ; N. S. Senthil and N. Sivaprakasan (1998). Growth promoting effects of Plant products on Silk worm. J. Sci. Ind. Res.; 57: 740745.

Nagda El-Sayed, A.A. (1989). Factors affecting the activity of Corpora allata and their hormonal involvement in certain metabolic progresses during metamorphosis of the castor and cotton leaf worms. Ph. D. Thesis Fac. Agric. (Helwan). Univ.

Nagda El-Sayed, A.A. (1994). Nitrogenous compounds as a factor affecting some biological and physiological characters of the eri - silkworm Phiolosamia ricini Boisd (Lepidoptera : Saturniidae). Com. In Sciand Dev. Res. 698 : (46) $219-231$.

Nagda El-Sayed, A.A. (1999). Evaluation of six mixtures of food additives on some bio-physiological and reproductivity parameters of the mulberry silkworm Bombyx mori L. Monofia J. Agric. Res., 24 (6): 19711986).

Nagda El-Sayed, A.A.; M. S. Moustafa and S. M. ElHattab.(1996). Effect of certain plant product extracts and vertebrate hormone on the mulberry silkworm Bombyx mori L. (Lepidoptera: Bombycidae). Adv. Agric. Res. 1 (1) : $68-79$.

Ngukue, K.; E. M. Muli and K. Rainas (2007) Larvae, cocoon and post-cocoon characteristics of Bombyx mori L. (Lepidoptera: Bombycidae) fed on mulberry leaves fortified with Kenyan royal jelly. J. Appl. Sci. Environ. Manage. 11(4) 85 - 89

Saikatsu, S.; K. Ikeno; Y. Hanada and T. Ikeno (1989). Physiologically active substances in the oral excreta produced by honey bee-effects of royal jelly on silkworm. Ohu Daigaku Shigakushi 16 (3):113 - 6. 
Samia El-Hattab, M. (1985). Biological studies on the eri silkworm Philosamia ricini Boisd with special reference to its nutritional reqirements. Ph. D. Thesis, Fac. of Agric. Alex. Univ., Egypt.

Sarker, A. A.; M. R. Haque; M. A. RAB. and N.Absar. (1995). Effects of feeding mulberry (Morus sp.) leaves supplemented with different nutrients of silkworm (Bombyx mori L.) current sci. 69 (2): 185 - 188.
Seidavi, A. R.; A. R. Bizhannia; R. Sourati and M. Mavvajpour (2005). The nutritional effects of different mulberry varieties on biological characters in silkworm. Asia Pac. J. Clin. Nutr. 14 (Suppl): S122

Steel, R. G. D. and J. H. Torrie (1981). Principles and procedures of statistic. A biometrical approach. 2nd Ed. McGraw. Hill Kogahusha Ltd. PP. 633.

Zah, C.; L. A. Marghitas; A. Matei. and N. Madus Mariana. (2011). The effect of dietary supplements on the development of Bombyx mori L. silkworms. Scientific papers : Ani. Sci. and Biotech., 2011, 44 (1).

\section{الملخص العربي}

\section{تأثيرإضافة بعض المواد الغذائية على إنتاجية ديدان الحرير التوتية}

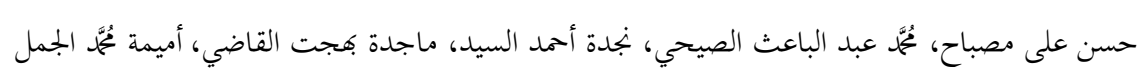

وقـد أدت أضـافة ومعاملـة أوراق التـوت بالتركيزات المختلفـة مـن

حبوب لقاح النخيل إلى زيادة معنوية القياسات البيولوجية والإنتاجية مقارنة بالكنترول. أما الخليط من عسل الموالح وحبوب لقاح النخيل

وكذلك بعض تركيزات من عسل الخروب وحبوب لقاح النخيل أدى

إلى زيادة معنويـــة في القياســات البيولوجيـــة والإنتاجيـــة بالمقارنــــة

$$
\text { بالكنترول. }
$$

$$
\begin{aligned}
& \text { يهدف هذا البحث دراسة تأثير بعض أنواع نحل العسل، حبوب } \\
& \text { لقـاح النخيـل وخلسيط منهمــا بأضـافتهما إلى أوراق التـوت بتركيـزات } \\
& \text { مختلفـة وذلك على بعض القياسـات البيولوجيـة والأنتاجيـة وتم ذلك لك } \\
& \text { بتغذيسة يرقـات العمرالحـامس على اوراق تـوت معاملـة وذلك لـزيادة } \\
& \text { الأنتاجية من الحرير والبيض. }
\end{aligned}
$$

